\title{
Polymorphism in intron 23 of the endothelial nitric oxide synthase gene (NOS3) is not associated with hypertension
}

\author{
Natalia Derebecka ${ }^{1}$, Marcin Hołysz ${ }^{1}$, Rafał Dankowski ${ }^{2}$, Michał Wierzchowiecki ${ }^{2}$ \\ and Wiesław H. Trzeciak ${ }^{1}$ 凶 \\ ${ }^{1}$ Department of Biochemistry and Molecular Biology, ${ }^{2}$ Cardiology Clinic, University of Medical \\ Sciences, Poznań, Poland
}

Received: 31 January, 2002; revised: 13 February, 2002; accepted: 21 February, 2002

Key words: nitric oxide synthase, gene polymorphism, intron 23, hypertension

\begin{abstract}
Nitric oxide (NO) is synthesised in the vascular endothelium by nitric oxide synthase (NOS3) and is an important factor in the regulation of blood pressure. Impaired synthesis of NO due to mutations in the NOS3 gene is associated with hypertension. To date several allelic variants of the NOS3 gene have been identified and their possible linkage with hypertension investigated.

We studied the distribution of genotypes and frequency of alleles of the G11T polymorphism in intron 23 of the NOS3 gene in patients with hypertension and in a control group of healthy individuals. The polymorphism was determined by PCR-RFLP analysis. The distribution of genotypes in the patients with hypertension and in the healthy individuals did not differ significantly from the values predicted from Hardy-Weinberg equilibrium for the general population. No major differences in the distribution of the G11T polymorphism in the patients and healthy individuals were found $(P>0.05)$.
\end{abstract}

In the cardiovascular system nitric oxide (NO) is an important vasorelaxant factor that also inhibits platelet adhesion and proliferation of smooth muscle cells [1]. NO is synthesised from L-arginine by endothelial nitric oxide synthase (NOS3) [2, 3]. The deficiency of NO may result from mutations in the NOS3 gene that is located on chromosome 7, comprised of 26 exons and constitutively expressed in the vascular endothelium [2, 4]. It has been hypothesized that the inhibition of NO synthesis in the blood vessel wall is associated with hypertension [4]. Direct evidence for the role of endothelial NOS in hyperten-

\footnotetext{
${ }^{\circledR}$ Corresponding author: Wiesław H. Trzeciak, Department of Biochemistry and Molecular Biology, University of Medical Sciences, H. Święcickiego 6, 60-781 Poznań, Poland; tel/fax (48 61) 865 9586; e-mail: trzeciak@am.poznan.pl

Abbreviations: dNTP, deoxyribonucleotides; MSSCP, multitemperature single-stranded conformational polymorphism; RFLP, restriction fragments length polymorphism; VNTR, variation in the number of tandem repeats.
} 
sion was provided by the observation that disruption of the NOS3 gene in knockout mice resulted in elevated blood pressure [5].

Several allelic variants of the NOS3 gene have been identified and evaluated for possible association with cardiovascular disease [6-11]. The majority of NOS3 gene polymorphisms have been found in introns (i.e., VNTR in intron 4; CA repeats in intron 13 ; A27C in intron 18, and G11T in intron 23).

The G11T polymorphism in intron 23 has not yet been widely investigated. Only two papers describing this polymorphism have been published to date. In order to detect the G11T transversion, hybridisation with allele-specific oligonucleotides (ASO) was applied and no association between this polymorphism and hypertension was found [9, 10].

The purpose of our investigation was to determine the association of intron 23 polymorphism of the NOS3 gene with the incidence of hypertension in the Polish population. In our study we applied PCR-RFLP analysis with the use of the restriction endonuclease $\mathrm{NmuCI}$.

\section{MATERIALS AND METHODS}

Subjects. The study group consisted of 108 Caucasian patients (men - 74, women - 34) with arterial hypertension, recruited in three clinical centres (Cardiology Clinic I, Cardiology Clinic II and Gynecological Endocrinology Clinic, University of Medical Sciences, Poznan). The patients ranged in age from 20 to 67 years (median age 51). Arterial hypertension was defined according to the criteria of the World Health Organization [12]. Secondary forms of hypertension were excluded based on extensive workup when indicated. Subjects with a history of extensive alcohol intake, oral contraceptive therapy, diabetes mellitus or renal failure were excluded from the study group. Blood pressure was measured in supine position using a mercury sphygmomanometer.
The control group included 118 healthy individuals matched with sex and age. The study protocol was approved by local Ethics Committee and written consents from the patients were obtained.

DNA preparation. Genomic DNA was isolated from peripheral blood leukocytes by the salting-out method. Fragments of the NOS3 gene, containing exon 23 and a part of intron 23 , were amplified by the polymerase chain reaction (PCR) using specific primers: F-5'-GGGACCTGATGGAGTGTC-3' and R-5'-CTCTGTCCCTAGATTGTGTG-3'. The expected length of the PCR products was $207 \mathrm{bp}$. The amplification reaction contained in $25 \mu \mathrm{l}$ : 0.5 $\mu \mathrm{g}$ of genomic DNA, $12.5 \mathrm{pmol}$ of each primer, $1 \mathrm{U}$ of DNA polymerase, $2.5 \mu \mathrm{l}$ of the reaction buffer $(10 \times)$ and $20 \mathrm{mM}$ dNTPs. The following conditions were applied: denaturation at $94^{\circ} \mathrm{C}$ for $3 \mathrm{~min}$ followed by 30 cycles of denaturation at $94^{\circ} \mathrm{C}$ for $30 \mathrm{~s}$, annealing at $54^{\circ} \mathrm{C}$ for $30 \mathrm{~s}$, extension at $72^{\circ} \mathrm{C}$ for $30 \mathrm{~s}$ and the final extension at $72^{\circ} \mathrm{C}$ for $7 \mathrm{~min}$. The PCR products and size marker pUC19 were separated by electrophoresis in $2 \%$ agarose gel and were visualised by staining with ethidium bromide.

Mutation analysis. The search for mutations was performed by the multitemperature single-stranded conformational polymorphism (MSSCP) method. The PCR products were separated in $8 \%$ nondenaturing polyacrylamide gel containing 7\% glycerol in $1 \times$ TBE buffer (Tris/borate/EDTA, pH 8.4) using the DNA-Pointer System (Kucharczyk TE, Poland). The electrophoresis was conducted at $30^{\circ} \mathrm{C}$ for $30 \mathrm{~min}$ then at $15^{\circ} \mathrm{C}$ for $30 \mathrm{~min}$. and finally at $4^{\circ} \mathrm{C}$ for $30 \mathrm{~min}$ and the bands were visualised by the silver staining technique.

In order to establish the reason for significant changes in migration of single-stranded DNA, a sequence analysis was conducted. The PCR products were purified using the DNA Gel-out kit. The sequencing reaction of the amplified fragment of intron 23 was conducted by asymmetric reamplification using the forward primer and dideoxynucleotides labelled with Cy5. The conditions of the reaction were 
as follows: denaturation at $94^{\circ} \mathrm{C}$ for $2 \mathrm{~min}$ followed by 30 cycles of denaturation at $94^{\circ} \mathrm{C}$ for $10 \mathrm{~s}$, annealing at $54^{\circ} \mathrm{C}$ for $30 \mathrm{~s}$ and extension at $72^{\circ} \mathrm{C}$ for $30 \mathrm{~s}$. The electrophoresis was performed in nondenaturing polyacrylamide gel using an automated DNA sequencer ALFexpress (Amersham Pharmacia Biotech, U.K.).

Polymorphism analysis. Restriction fragment length polymorphism (PCR-RFLP) analysis was used to screen the polymorphism in intron 23 in order to determine the allele frequencies in the investigated group. The PCR products (207 bp in length) were digested at $37^{\circ} \mathrm{C}$ for $5 \mathrm{~h}$ with the restriction endonuclease $\mathrm{NmuCI}$ followed by separation in $7 \%$ nondenaturing polyacrylamide gel and were visualised by the silver staining technique. The digestion of PCR products normally gives rise to that of the general population in Hardy-Weinberg equilibrium by using the $\chi^{2}$ test. The distribution of genotypes between the patients and controls was compared using the MannWhitney U-test. The relations between allelic frequencies were determined using $\chi^{2}$ analysis. Statistical significance was accepted at $P<0.05$.

\section{RESULTS AND DISCUSSION}

The MSSCP analysis of the amplified fragment of the NOS3 gene showed three different banding patterns (Fig.1). Sequence analysis revealed three corresponding genotypes (Fig. 2). Following PCR-RFLP analysis all the patients and the controls were divided into three groups: $\mathrm{G} / \mathrm{G}, \mathrm{G} / \mathrm{T}$ and $\mathrm{T} / \mathrm{T}$,

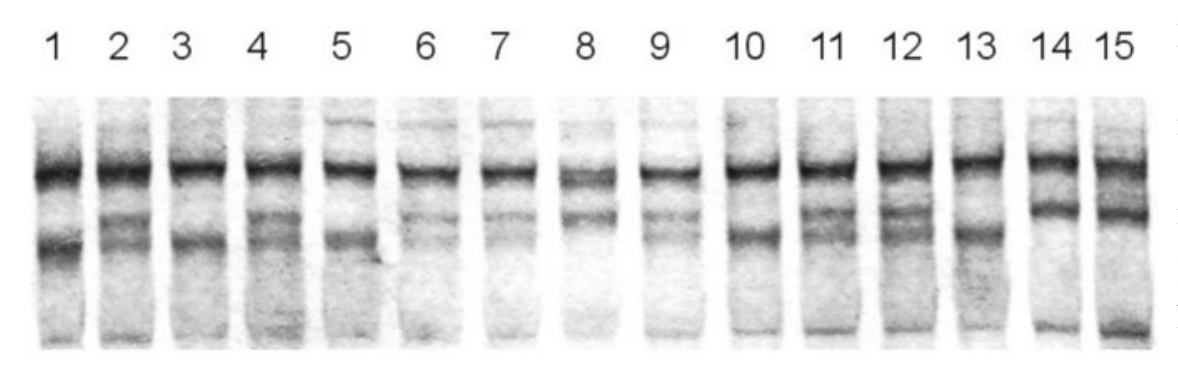

Figure 1. Multitemperature single-stranded conformational polymorphism (MSSCP) analysis of the amplified fragment of the NOS3 gene.

Lane 1-14, patients; lane 15, healthy individual as control.

two fragments (185 and $22 \mathrm{bp}$ ). The G11T transversion in intron 23 creates an additional $\mathrm{NmuCI}$ restriction site and the product is digested into three fragments (160, 25 and $22 \mathrm{bp})$.

Statistical analysis. All statistical analyses were performed with the Statistica for Windows v. 5.1 software. The numbers obtained for each NOS3 genotype were compared with according to their genotype (Table 1). The distribution of genotypes in the patients and the controls did not differ significantly from the values expected for the general population in Hardy-Weinberg equilibrium $(P>$ 0.05). No major differences in the distribution of the G11T polymorphism in the affected individuals and control groups were found $(P=0.32)$.

Table 1. The distribution of genotypes and allele frequencies in patients with idiopathic hypertension and in healthy individuals

\begin{tabular}{lccccccccc}
\hline \multirow{2}{*}{ Group } & $\begin{array}{c}\text { Group } \\
\text { size }\end{array}$ & \multicolumn{2}{c}{$\begin{array}{c}\text { Homozygotes } \\
\mathrm{T} / \mathrm{T}\end{array}$} & \multicolumn{2}{c}{$\begin{array}{c}\text { Heterozygotes } \\
\text { G/T }\end{array}$} & \multicolumn{2}{c}{$\begin{array}{c}\text { Homozygotes } \\
\text { G/G }\end{array}$} & \multicolumn{2}{c}{$\begin{array}{c}\text { Allele frequencies } \\
\text { (\%) }\end{array}$} \\
\cline { 3 - 11 } & & $\mathrm{n}$ & $\%$ & $\mathrm{n}$ & $\%$ & $\mathrm{n}$ & $\%$ & $\mathrm{~T}$ & $\mathrm{G}$ \\
\hline Patients & 108 & 16 & 14.8 & 52 & 48.2 & 40 & 37.0 & 39.0 & 61.0 \\
Control & 118 & 13 & 11.0 & 55 & 46.6 & 50 & 42.4 & 34.3 & 65.7 \\
\hline
\end{tabular}

Allelic frequencies [patients $v s$ control] $P=0.31\left(\chi^{2}\right.$ test). Genotype distribution [patients $v s$ control] $P=0.32$ (U-test). 
A.

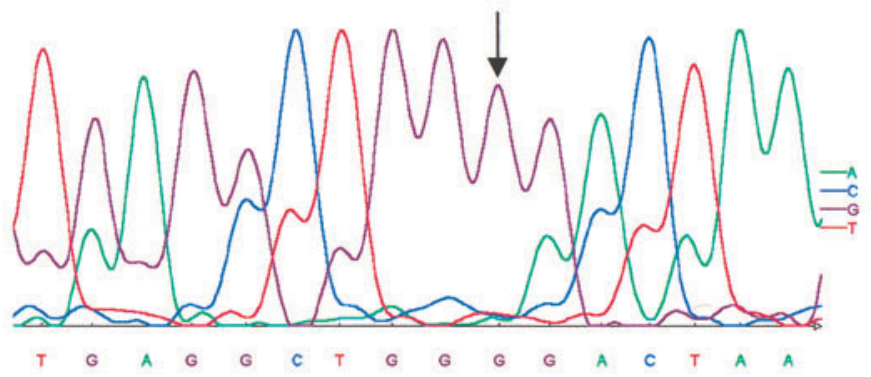

B.

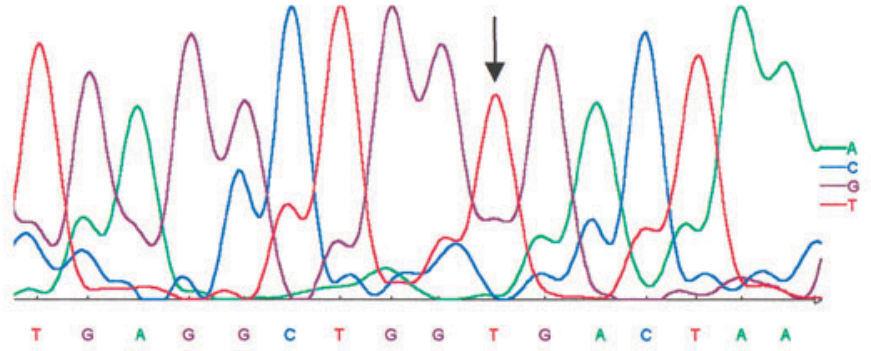

C.

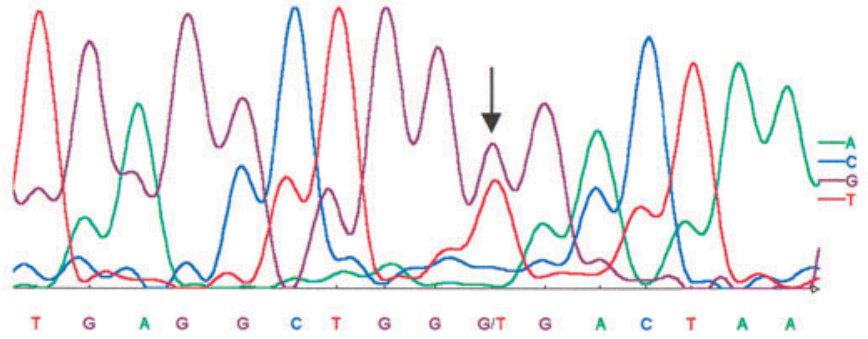

Figure 2. Sequence analysis of the amplified fragment of intron 23 of the NOS3 gene.

A. homozygote G; B. homozygote T; C. heterozygote $\mathrm{G} / \mathrm{T}$.

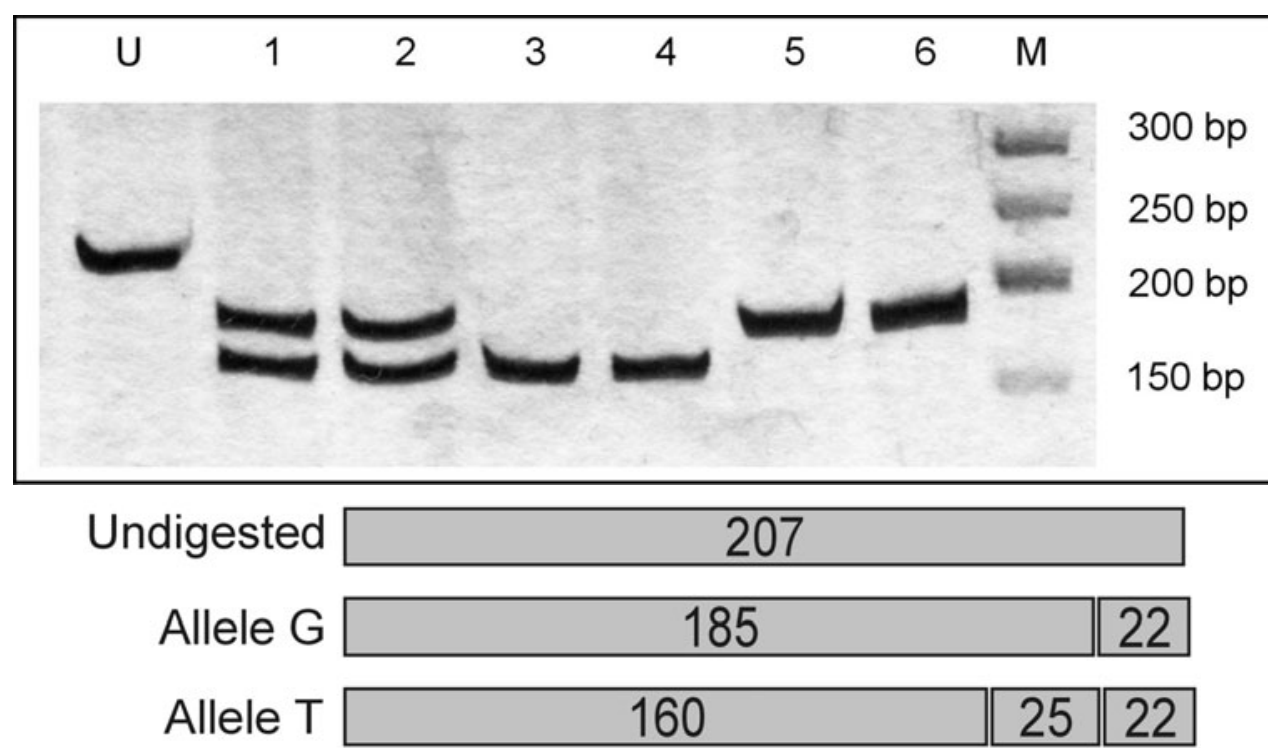

Figure 3. A. Typical result of PCR-RFLP analysis of the amplified fragment of the NOS3 gene.

$\mathrm{U}$, undigested PCR product; lanes 1 and 2, heterozygotes G/T; lanes 3 and 4, homozygotes T/T; lanes 5 and 6 , homozygotes G/G; M, DNA size marker.

B. Expected lengths of the PCR-RFLP products. 
The present work shows that the G11T polymorphism of the NOS3 gene is not associated with hypertension. These findings support previous studies [9, 10] indicating that the G11T polymorphism in intron 23 of the NOS3 gene does not constitute a significant risk factor for hypertension. Present results suggest that this polymorphism is common in the Polish population. The estimation of the frequency of the mutant allele would, however, require investigation of larger groups of both patients and healthy individuals.

In our opinion the G11T transversion might cause aberrant splicing of the primary transcript of the NOS3 gene, since it generates a five-nucleotide motif identical to the original 5 'splice site. This could influence the aminoacid sequence and affect the activity of the enzyme. However, the analysis of splice variants of the NOS3 gene has not been conducted.

Other polymorphisms of the promoter, coding regions and introns of the NOS3 gene have been reported [6-11]. Some of these polymorphisms may be associated with hypertension. It is very difficult to find a correlation between the NOS3 gene polymorphisms and the occurrence, frequency and development of hypertension. The main reason for these difficulties is the complexity of this disease that may depend on many as yet poorly defined risk factors. Further research might elucidate, at least in part, the role of the polymorphism of the NOS3 gene in the origin and development of hypertension.

\section{R E F E R E N C E S}

1. Ignarro, L.J. (1996) Physiology and pathophysiology of nitric oxide. Kidney Int. (Suppl.), 55, 2-5.

2. Derebecka, N., Hołysz, M. \& Trzeciak, W.H. (2000) Genes of nitric oxide synthases: Structure, regulation of expression, protein products. Postępy Biochemii 2, 130-139 (in Polish).
3. Chen, P.F., Tsai, A.L., Berka, V. \& Wu, K.K. (1996) Endothelial nitric oxide synthase. J. Biol. Chem. 271, 14631-14635.

4. Marsden, P.A., Heng, H.H.Q., Scherer, S.W., Stewart, R.J., Hall, A.V., Shi, X.M., Tsui, L.C. \& Schappert, K.T. (1993) Structure and chromosomal localization of the human constitutive endothelial nitric oxide synthase gene. $J$. Biol. Chem. 268, 17478-17488.

5. Huang, P.L., Huang, Z., Mashimo, H., Bloch, K.D., Moskowitz, M.A., Bevan, J.A. \& Fishman, M.C. (1995) Hypertension in mice lacking the gene for endothelial nitric oxide synthase. Nature 377, 239-242.

6. Wattanapitayakul, S.K., Mihm, M., Young, A.P. \& Bauer, J.A. (2001) Therapeutic implication of human endothelial nitric oxide synthase gene polymorphism. Trends Pharmacol. Sci. 22, 361-368.

7. Pulkkinen, A., Viitanen, L., Kareinen, A., Lehto, S., Vauhkonen, I. \& Laakso, M. (2000) Intron 4 polymorphism of the endothelial nitric oxide synthase gene is associated with elevated blood pressure in type 2 diabetic patients with coronary heart disease. J. Mol. Med. 78, 372-379.

8. Hingorani, A.D., Liang, C.F., Fatibene, J., Lyon, A., Monteith, S., Parsons, A., Haydock, S., Hopper, R.V., Stephens, N.G., O’Shaughnessy, K.M. \& Broen, M.J. (1999) A common variant of the endothelial nitric oxide synthase (Glu298 $\rightarrow$ Asp) is major risk factor for coronary artery disease in the UK. Circulation 100, 1515-1520.

9. Bonnardeaux, A., Nadaud, S., Charru, A., Jeunemaitre, X., Corvol, P. \& Soubrier, F. (1995) Lack of evidence for linkage of the endothelial cell nitric oxide synthase gene to essential hypertension. Circulation 91, 96-102.

10. Miyamoto, Y., Yoshihiko, S., Kajiyama, M., Yoshimura, M., Shimasaki, Y., Nakayama, M., Kamitani, S., Harada, M., Ishikawa, M., Kuwahara, K., Ogawa, E., Hamanaka, I., 
Takahashi, N., Kaneshige, T., Teraoka, H., Akamizu, T., Azuma, N., Yoshimasa, Y., Yoshimasa, T., Itoh, H., Masuda, I., Yasue, H. \& Nakao, K. (1998) Endothelial nitric oxide synthase gene is positively associated with essential hypertension. Hypertension 32, 3-8.

11. Nakayama, M., Yasue, H., Yoshimura, M., Shimasaki, Y., Kugiyama, K., Ogawa, H., Motoyama, T., Saito, Y., Ogawa, Y.,
Miyamota, Y. \& Nakao, K. (1999) T-786 $\rightarrow$ C mutation in the 5 '-flanking region of the endothelial nitric oxide synthase gene is associated with coronary spasm. Circulation 99, 28642870 .

12. World Health Organization-International Society of Hypertension guidelines for the management of hypertension. Guidelines subcommittee. (1999) J. Hypertens. 17, 151-183. 